\title{
Article
}

\section{Democratic leadership: a charming solution for nursing's legitimacy crisis}

\author{
McKeown, Mick and Carey, Lynda \\ Available at http://clok.uclan.ac.uk/11932/ \\ McKeown, Mick ORCID: 0000-0003-0235-1923 and Carey, Lynda (2015) \\ Democratic leadership: a charming solution for nursing's legitimacy crisis. \\ Journal of Clinical Nursing, 24 (3-4). pp. 315-317. ISSN 0962-1067
}

It is advisable to refer to the publisher's version if you intend to cite from the work. http://dx.doi.org/10.1111/jocn.12752

For more information about UCLan's research in this area go to

http://www.uclan.ac.uk/researchgroups/ and search for <name of research Group>.

For information about Research generally at UCLan please go to http://www.uclan.ac.uk/research/

All outputs in CLoK are protected by Intellectual Property Rights law, including Copyright law. Copyright, IPR and Moral Rights for the works on this site are retained by the individual authors and/or other copyright owners. Terms and conditions for use of this material are defined in the policies page.

\section{CLoK}

Central Lancashire online Knowledge www.clok.uclan.ac.uk

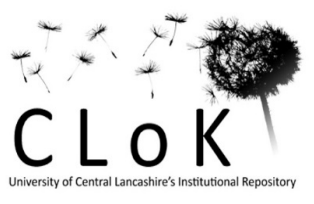




\section{Editorial. Democratic leadership: a charming solution for nursing's legitimacy crisis}

Journal of Clinical Nursing, 24, 315-317, doi: 10.1111/jocn.12752

Mick McKeown, University of Central Lancashire

Lynda Carey, Edge Hill University

Plato referred to democracy as a charming form of government. In the UK the impact of the Mid Staffordshire Inquiry (2013), Berwick (2013), and Clwyd-Hart Reviews (2013) has fundamentally influenced the public perception of nurses, resulting in a significant legitimacy crisis for the profession. Nursing has arguably lost some of its charm with the public and the very experience of nursing work has become stressful, beset with uncertainty, and unrewarding for many practitioners. These trials and tribulations appear to be endemic and not confined to the UK. Here we argue that nursing can recover some of its esteem and lay claim to renewed legitimacy if services were to adopt more democratic systems of management. Ultimately, there is a case for moving beyond a mere rhetoric of 'democratic leadership', as valued in some education and research contexts, to actually realise in practice a new cadre of nurse leaders steeped in an ethos of participation, cooperation and empowerment.

\section{What has gone wrong?}

Bauman identifies a state of liquid modernity, within which professional disciplines such as nursing flounder as previous certainties and organisational anchorage points, even ethical frameworks, are dismantled within an ever expanding neo-liberal polity (Randall \& McKeown 2014). In particular, health care workers have been beleaguered by a slew of politically driven, top-down change management initiatives, disseminated to grass-roots practitioners without meaningful opportunity to influence genesis or implementation. This is increasingly evident post-Francis, with politicians eager to visibly identify and resolve issues centrally whilst extolling the importance of local leadership.

Indeed, Francis's recommendations largely constitute a plea for more and better nurse leadership. This begs the question, beyond an emphasis on compassion, what sort of leadership? Most NHS managers have not been trained for leadership. There has been a recent proliferation of nurse leadership curricula, with a certain focus upon theories of participation, voice, partnership and workforce empowerment. There is less evidence that novel leadership ideas percolate into practice. If anything, fairly rigid and authoritarian 
hierarchies persist as the norm, and much time is wasted on discipline and grievance. Furthermore, inter-disciplinary dominions continue to subjugate and disempower nurses.

Arguably, the relative lack of democracy and participation in workplace decision making is one source of diminished staff morale. This highlights a typically neglected aspect of discourse on nurse leadership - the importance of power relations (Cleary et al. 2011). A lack of control over work pattern, content and intensity leads to alienation in role. Associated negative impact upon caring relationships has profound consequences for sense of self as a compassionate, 'good' nurse. This is particularly problematic in the case of nurses' work as it contradicts the potential to realise ideals of autonomy in practice. The degradation of health care work associated with neoliberal efficiencies has undermined the capability of nurses to exert influence and involvement at all stages of the nursing process or patient journey. With jobs fragmenting into tasks, many of them impersonal and administrative, scientific management triumphs over salutogenic principles.

\section{What can be done?}

Nurse education has long been influenced by humanistic psychologies and progressive theories of learning, such as advocated by Paulo Freire. These frame education as an empowering, participatory process enacted amongst peers. For the emancipatory potential to be realised: 'respect for the autonomy and dignity of every person is an ethical imperative and not a favour that we may or may not concede to each other' (Freire 1998: 59). This critical pedagogy is essentially relational, democratic and political. Within groups who come together to learn, conscientisation, or political awakening, is brought about in tandem with mutual understanding, love and hope.

Many of the aforementioned nurse leadership courses have distinctly Freirian overtones and promote distributed decision making, collective leadership and the importance of real, effective team working (West 2012). An emphasis on transformational leadership to support both improved quality of care and address cost efficiency and effectiveness challenges raises expectations that nurses are in a position to lead and change practice. In reality the complexity of healthcare provision, with competing professional demands, resource restrictions and top down decision making severely limits the potential of bottom up change to be acknowledged and actualised. Furthermore, favoured models of transformational leadership have been questioned for uncritical adoption and deficits in authenticity, integrity and ethical practice when vertical rather than horizontal leadership structures are emphasised (Hutchinson \& Jackson 2013). 
Alongside pedagogical developments, advances in the research context have also increasingly promoted inclusive, democratic methods, such as participatory action research, appreciative inquiry, and experience based co-design. The best of these view health care teams and service users as a community, with potential to work together to imagine and implement new ways of working and relating to each other. The irony is that demonstrable benefits of such approaches have to be considered on a project by project basis. An equally plausible prospect might be to apply the principles and practices of these methods wholesale into the management and organisation of health care services. This would represent a democratisation of the labour process and would also allow for such workplace democracy to be inclusive of other important perspectives, such as service users and informal carers.

One of the key lessons from Mid Staffordshire is that service user and carer voices were not listened to when concerns over inadequate care were highlighted. Interestingly, some nurses and union representatives also initially raised concerns but were ignored by management, and the Francis Report recommends better systems for supporting nursing union representation and attending to employee voice. A wealth of government policy has accelerated interest in service user or carer involvement in the planning and delivery of public services (and in education and research) and nurses have been at the heart of supporting these endeavours. Some of the more interesting examples employ implicitly deliberative and democratic approaches and have engineered high quality alliances between staff and service users engaging in key aspects of decision making with meaningful, if modest, impact at organisational levels (McKeown et al. 2014). Yet, most of what passes for service user involvement is not influential at the most important levels of large health care organisations and has not resulted in transformative change.

In a variety of employment contexts different forms of workplace democracy have been enacted, positively influencing employee wellbeing and organisational efficiency. On the whole, however, western businesses that have supported workplace democracy have favoured representative rather than participatory or prefigurative forms. If it were not for the encroachment of neoliberalism into the sector, a strong case could be made that public services, such as health care, ought to be more opportune environs for considering extensions of democratic voice in how their core work is organised. 
Typically, and for good reasons, appeals for increased workplace democracy are driven by trade unions. Unions themselves, however, are beset by their own legitimacy crisis; losing members and public support in the face of industrial decline and austerity. Union renewal tactics revolve around approaches to organising, aimed at revitalisation of social ties between members and extending social capital beyond the workplace to alliances with communities and movements with shared social justice interests (McKeown, Cresswell \& Spandler 2014). These organising efforts have not necessarily reversed membership losses, but they have provoked critical reflection on democracy and voice. Indeed, a recent review of UK union organising strategies concludes that workplace democracy goals are a logical extrapolation of thinking about union renewal (Simms et al. 2013). Given public service organisations typically subscribe to notions of employer-union partnership, there is no axiomatic impediment to further enhancement of worker voice.

\section{New model leaders}

Taken together, approaches to supporting worker and service user voice make a virtue of solidarity and cooperation and should be enjoyable (Sennett 2012) or ameliorate the remarked upon alienation in patient and worker roles. In nursing and nurse education contexts, models of distributed, horizontal, 'servant' leadership, vested across the workforce have been contrasted with the yearning for visionary, charismatic manager-leaders (Jackson 2008, Jackson \& Watson 2009). A new class of nurse leaders committed to a public service ethos could harness participatory, deliberative democratic ideals and make real the contention that communication can be the driver for progressive change (Habermas 1987). As we have seen, this would reconnect with nursing's historical affinity for humanistic and Freirian values and provide a potent riposte to the denigration of nursing identity and degradation of nurses' work gathering pace in late capitalism. Indeed, Bevan and Fairman's (2014) call to action for a novel, radical approach to leadership, with democracy, social connectivity and community engagement at the centre of practice, offers hope for nurse leaders committed to delivering compassionate care.

Such nurse leaders would be facilitative rather than directive, freeing up time to consider wider aspects of innovation, evidence and public participation. The latter point is crucial because any democratic systems that emerge would be imperfect without the inclusion of service user, carer and public voice. Essential leadership skills and attributes must of necessity include listening, patience and humility. There must also be the resilience and flexibility to recognise that the sort of dialogue that will arise in an authentic, inclusive democracy of this kind will inevitably be unsettling and unsettled. Such democratisation will 
also, however, be ripe with possibilities: the promise of truly understanding what we mean by empowered and emancipatory care. An exceedingly charming possibility indeed. 


\section{References}

Bevan, H \& Fairman, S (2014) The new era of thinking and practice in change transformation: A Call to Action for Leaders of Health and Care, NHSIQ (NHS Improving Quality). http://media.nhsiq.nhs.uk/whitepaper/html5/index.html?page=1

Berwick, D. (2013) A promise to learn - a commitment to act, Improving the Safety of Patients in England. Department of Health, London.

Cleary, M., Horsfall, J., Deacon, M. \& Jackson, D. (2011) Leadership and mental health nursing. Issues in Mental Health Nursing, 32, 632-639.

Clwyd, A. \& Hart, P. (2013) A Review of the NHS Hospitals Complaints System, Putting Patients Back in the Picture. Department of Health, London.

Francis, R (2013) Report of the Mid Staffordshire NHS Foundation Trust Public Inquiry. Stationary Office, London.

Freire, P. (1998) Pedagogy of freedom: ethics, democracy and civic courage. Rowman \& Littlefield, Lanham, Maryland.

Hutchinson \& Jackson, D. (2013) Transformational leadership in nursing: towards a more critical interpretation. Nursing Inquiry, 20 (1): 11-22.

Jackson, D. (2008) Servant Leadership in Nursing: A framework for developing sustainable research capacity in nursing. Collegian, 15, 27-33

Jackson, D. \& Watson, R. (2009) Editorial: Lead us not. Journal of Clinical Nursing, 18, 1961-1962.

McKeown, M., Cresswell, M. \& Spandler, H. (2014) Deeply engaged relationships: alliances between mental health workers and psychiatric survivors in the UK. In B. Burstow, B. A. LeFrancois and S. L. Diamond (eds) Psychiatry disrupted: theorizing resistance and crafting the (r)evolution. McGill/Queen's University Press, Montreal, QC. 
McKeown, M., Jones, F., Wright, K., Spandler, H., Wright, J., Fletcher, H., Duxbury, J., McVittie, J., Simon. \& Turton, W. (2014) It's the talk: a study of involvement practices in secure mental health services. Health Expectations, DOI: 10.111/hex.12232

Randall, D. \& McKeown, M. (2014) Failure to care: nursing in a state of liquid modernity? Journal of Clinical Nursing, 23, 766-767.

Sennett, R. (2012) Together: The Rituals, Pleasures and Politics of Cooperation. Allen Lane, London.

Simms, M., Holgate, J. \& Heery, E. (2013) Union Voices - Tactics and Tensions in UK Organizing. ILR Press, Ithaca.

West, M.A. (2012) Effective Team Work (3 ${ }^{\text {rd }}$ Edition). PBS Blackwell, Oxford 